\title{
Ideologies in Energy Transition: Community Discourses on Renewables
} Petra Berg, Rumy Narayan and Arto Rajala

\author{
" You have to know the past to understand the present."
}

Carl Sagan

American astronomer

\begin{abstract}
This paper examines discourses in five Finnish municipalities' energy transition processes to identify and explain different ideological discourses among its members. The study fills a gap in research extending the idea of sense making to capture the ideologies that hide in discourses during socio-technical transitions. We identify three types of ideological discourses labelled as Clan, Solarpunk and Native. The implications of the ideologies embedded in municipal, multipartner networks that participate in energy transition affect who will be heard in a local context. This impacts future choices directly related to sustainability outcomes. We propose that discourses in these multi-partner networks, conceptualized from the perspective of municipal energy systems, help us to uncover underlying ideologies that imperil change. And yet at the same time, these revelations offer opportunities for sustainability-oriented innovation.
\end{abstract}

\section{Introduction}

Energy transition is a system-wide ongoing process during which transformative initiatives and actions may influence peoples' responses to energy. Energyrelated behaviour depends on socio-economic incentive structures, as well as political, institutional, and organizational frameworks (Mannberg et al., 2014). Previous research indicates that strategic orientations regarding energy transitions are often affected by conflicting ideologies (Stirling, 2014). However, this issue has received little attention in transition literature (Geels, 2020).

We believe that especially local level interactions (Dóci et al., 2015) and their resulting views, are critical during energy transition policy making (Sarrica et al., 2016) as well as innovation processes (Ringberg et al., 2019). Municipalities, cities, and other communities are in a key position to further the transition to more sustainable low carbon and cost-effective energy systems (Kostevšek et al., 2016). The energy interactions imply a network of actors (Van Der Schoor, 2015), and thus a social fabric (Wittmayer et al., 2017). As municipalities are deemed appropriate micro-units for establishing sustainable energy systems (Burton \& Hubacek, 2007), our study focuses on ideologies and sense making at that level involving actors in the social fabric.

We expect that taking into account the contexts of transition arenas can enhance managerial sense making, while at the same time infusing it with an understanding of the contemporary environmental context of marketing and business strategy. From the perspective of transition studies (Geels, 2020), the process of energy systems transformation in the last few decades has resulted in coordinating energyrelated infrastructures and paving the way for new kinds of multi-actor configurations. One such transformation relates to an upcoming transition from current centralized energy systems to more decentralized ones based on renewables (Ruggiero et al., 2015). Such system-wide transformations offer unique co-evolutionary opportunities for innovation and a stream of academic literature has emerged that attempts to understand the dynamics and directions of such socio-technical transformations (Sengers et al., 2016). 


\title{
Ideologies in Energy Transition: Community Discourses on Renewables
}

\author{
Petra Berg, Rumy Narayan and Arto Rajala
}

This paper attempts to turn the focus on how the socalled meso-level actors (Schenk et al., 2007) in five Finnish municipalities engage with the idea of sustainable energy self-sufficiency. Here, we define the meso-level actors as a compilation of local decision makers, politicians, businesspersons, researchers, innovators, consultants, NGO's, project leaders, as well as "prosumers" (a mixture of producers and consumers). Thus, individuals are seen as actors with existing roles in a socio-technical system, or with the possibility and interest of entering it (Wittmayer et al., 2017). These actors might either maintain, or challenge, the current regime and, through the acting out of ideological tensions, affect the legitimacy (Press et al., 2014) of energy innovations. By addressing ideological drivers that affect the adoption of sustainable, renewable energy innovations, the aim of this paper is to identify and explain different ideological discourses among members of a municipality. We suggest that uncovering and exploring some of the connections between ideologies and sense making can offer new insights into characteristics and capabilities that could then help identify new decentralized, sustainable energy innovations (Farla et al., 2012).

The paper is organized as follows. After this introduction section, the paper reviews literature on energy transition and ideological drivers of renewable energy adoption in five Finnish municipalities. The paper then describes the data involved and methods of analysis. Thereafter, it provides results from a qualitative discourse analyses, and, finally, concludes with a discussion on key findings, including their contributions to theory and practice, as well as limitations and future research avenues.

\section{Literature Review}

\section{Municipal energy transitions}

Municipalities are in direct contact with local stakeholders and play an important role in the transition from carbon-based energy to renewable energy systems (Kostevšek et al., 2016). National energy strategies provide normative and legislative structures that maintain (or try to disrupt) the legitimized energy system by providing guidelines, rules, and research, as well as funding opportunities (Kainiemi et al., 2020). Following the above logic, we consider that municipal, meso-level actors construct their energy roles (Wittmayer et al., 2017) inside a framework of institutionalized-legal, social, economic, knowledge, and belief systems (Press et al., 2014). What is decided outside of municipalities by national governments, the EU, and Globally (COP 21) needs to be considered and acted upon locally (Sarrica et al., 2016). As an example of how the ongoing (global) development has changed the traditional roles of producers and consumers in energy markets is the way consumers have also become producers of energy, also known as "prosumers"; agents that both produce and consume electricity (Olkkonen et al., 2017).

In addition to exogenous influences, another important context affects municipal energy transitions: The unique geography of natural-, material- (existing technology and production facilities), and knowledge-related (education, profession, age, and gender) resources available (Coenen et al., 2012). These are embedded in the local cultural "doxa" (Press et al., 2014), a dominant paradigm with taken for granted personae, values, symbols and beliefs, a sociocultural belief-system that provides a collective agreement and map on "how to make use of those" (Kilbourne et al., 1997), affecting the roles actors can take or can be given (Avelino \& Wittmayer 2016).

\section{Ideologies and Sense Making}

Adhering to the fact that transitions include aspirations far more complex than the choice of cleaner technology (Geels, 2020), the focus turns towards so-called intangible drivers, such as mind-sets and belief-systems embedded in transition processes. These are expressed in and can be explored as "ideological discourses" (Van Dijk, 2006). The socio-technical transition literature recognizes the role of discourses in learning and adaptation, as well as in facilitating or challenging transitions, as they connect directly with policy and institutions (Späth \& Rohracher, 2010). In this paper we explore how local actors use their ideologies and beliefs (Haase \& Raufflet, 2017) to make sense of and participate in municipal energy transitions. By conceptualizing ideology as a "sense making" resource (Mees-Buss \& Welch, 2019) we open up to the perspective that sense making mediates between deep structures (ideology) and discourse as a surface expression imbued with ideology (Van Dijk, 2006).

Our perspective is that expectations emerging during an energy transition process require actors to consider the 


\title{
Ideologies in Energy Transition: Community Discourses on Renewables
}

\author{
Petra Berg, Rumy Narayan and Arto Rajala
}

possibility of needing a new socio-technical order in contrast to their current reality (Wittmayer et al., 2017). The way people make sense of and give meaning to things is rooted in the socio-cultural context they are born and socialized into (Giesler \& Veresiu, 2014; Humphreys, 2014). The effects of inherited beliefsystems often remain opaque in day-to-day interactions (Kilbourne \& Mittelstaedt, 2012), as they have become a legitimized part of habits, and, thus considered as a part of socially constructed reality (Berger \& Luckmann, 1967).

Ideologies are, primarily, based on ideas and, thus part of our belief-systems (Haase \& Raufflet, 2017). There are no private, personalised ideologies; instead, they are always socially shared beliefs by members of a group regarding social representations that define their identity. This means a shared understanding of fundamental conditions and "ways of existence and reproduction" (Van Dijk, 2006: 116). We explore the sense making and "enactment" (Weick, 1995) feature of ideology, by seeing it as a forward visioning force (Mees-Buss \& Welch, 2019) that interacts with culture (Marion, 2006). Ideology builds upon collective beliefsystems and knowledge structures about "how things are and why", which support institutionalized ways of doing things that help avoid chaos in decision making and action (Haase \& Raufflet, 2017).

\section{Ideological discourses}

All discourse is ideologically bounded and grounded (Eagleton, 2007), since "we produce, disseminate, and consume ideologies all our lives, whether we are aware of it or not" (Freeden, 2003:1 cited in Press et al., 2014: 104). Discourses can be approached as a system of statements which constructs an object (Salignac, 2012) and in choosing so, we explore how structured sets of texts come to function as reality constructors, which help constitute the social phenomena in question. It is assumed, that ideologies are largely expressed and acquired by discourse, so when group members explain, motivate, or legitimate their (group-based) actions, they typically do so in terms of ideological discourse (Van Dijk, 2006). Following the constructionist logic toward social phenomena (see Berger \& Luckmann, 1967), we focus the research here upon specific ways in which local renewable energy is produced discursively. We link concepts present in the "discursive universe" of talk about renewable energy, in particular ways by several actors with their own agendas.

\section{Methodology}

\section{Research context}

Finland has set its national goal (ym.fi, 2019) to become a carbon neutral society by 2035 , entailing a need for rapid decarbonisation, especially in the mobility, housing, and industry sectors. Municipalities have a central role in Finnish energy transition, as they are responsible for implementing the national energy and climate strategy and its goals in local contexts. In this study, data was collected by utilizing the Energy SelfSufficient Regions (ESSR) project led by the Levón Institute at the University of Vaasa (2017-2019). It involved five Finnish municipalities, which are situated in the regions of Ostrobothnia (Vaasa/Vähäkyrö and Kristinestad), Central Ostrobothnia (Perho), and Lapland (Tervola and Sodankylä). The ESSR project utilized the so-called Energy Village concept developed by the Levón Institute (Peura et al., 2018). The concept was initially developed to utilize economic opportunities around renewable energy sources (RES) for actors in village communities.

Firstly, others in the project calculated the energy balances for the five participating municipalities. This calculation included the reported amount of electricity consumed, heat and transport fuel used, accompanied by an assessment of the bioenergy and projected wind energy potentials. In general, the energy balance provides an overview of how much money people in the village are spending in energy-related consumption each year. This was used as a starting point for a SWOT analysis carried out together with local actors.

In the first meeting, a SWOT analysis was made, then in the next meeting discussed in depth the results of the SWOT analysis. Here, deliberative democracy-related tools such as the World Café method were used to make sure that the voices of all participants got heard. Based on the visions and illustrations created, thereafter a roadmap was developed for renewable energy production as well as energy efficiency for each municipality. Finally, the ESSR project arranged a kickoff seminar for local actors to engage them in developing potential businesses and new projects. 


\title{
Ideologies in Energy Transition: Community Discourses on Renewables
}

\author{
Petra Berg, Rumy Narayan and Arto Rajala
}

\section{Data collection}

In exploring ideologies in municipal energy transition dynamics, we used a discourse analysis (Jorgensen \& Phillips, 2002). Researchers attended, observed and recorded project meetings and workshops. We enriched this ethnographic approach (see Ellis, 2007) by interpreting the findings though observation and field notes. For the discourses to remain natural and without interference, the researchers mostly remained in the role of observers. Regarding ethical considerations, the researchers always introduced themselves to the participants at the beginning of the workshops and asked for permission to record. Throughout the project, the participants were invited to the meetings and workshops by the ESSR project, either with help from the local contact person (usually someone working for the municipality) or directly via the local newspapers and Facebook pages. To assure the participants' anonymity, we have used fictive names in the quotes. Table 1 . gives an overview of the empirical data collected.

\section{Data analysis}

Our data analysis followed the standard procedures and principles of discourse analysis (Jorgensen \& Phillips, 2002). The analysis process followed the abductive approach by firstly capturing emerging structures from the data sets, and then, comparing them to findings in the extant literature. Our focus was upon how municipal stakeholders structure their social schema regarding renewable energy, for example, categories that cognitively represent major social dimensions in groups, such as membership criteria, typical actions, goals, norms, and values (Van Dijk, 2006). To excavate deep ideological structures, we looked for the "zones of conflict" (Mees-Buss \& Welch, 2019), where people in one discourse are openly questioning or trying to persuade those in others, based on either real conflicting ideas, or a perceived contradictory ideology (Press et al., 2014). We can follow or "read" the value-laden, lexical expressions that group members share when they talk, and the presuppositions they make in explaining cause-and-effect relationships (Van Dijk, 1998). Thus, adhering to the above-mentioned logic, all the transcriptions were thoroughly read and sentences about "what, how, who, and why" regarding local energy were coded into categories.

We used NVIVO software to categorize emerging textual structures and arranged them according to larger themes such as "economic opportunities comes from local biogas", or "environmental issues are restricting

Table 1. List of empirical materials

\begin{tabular}{|c|c|c|c|}
\hline $\begin{array}{l}\text { Region } \\
\text { (Municipality) }\end{array}$ & $\begin{array}{l}\text { Number } \\
\text { of } \\
\text { meetings } \\
\text { (year) }\end{array}$ & $\begin{array}{l}\text { Background (and number) of } \\
\text { participants: MG (representatives of } \\
\text { municipality), BF (local } \\
\text { businesses/farmers), EC (energy } \\
\text { companies), CA (consulting } \\
\text { agencies) }\end{array}$ & $\begin{array}{l}\text { Number of } \\
\text { Participants \& } \\
\text { Gender F } \\
\text { (female)/M } \\
\text { (male) and } ~ \\
\text { (average age) }\end{array}$ \\
\hline $\begin{array}{l}\text { 1. Ostrobothnia } \\
\text { (Vaasa/Vähäkyrö) }\end{array}$ & $1(2017)$ & MG (1), BF (8) & $1 \mathrm{~F} / 8 \mathrm{M}(\sim 50)$ \\
\hline $\begin{array}{l}\text { 2. Ostrobothnia } \\
\text { (Kristinestad) }\end{array}$ & $2(2018)$ & $\begin{array}{l}\text { MG (2), BF (1), CA (1) } \\
\text { MG (4), BF (1), CA (2) }\end{array}$ & $\begin{array}{l}2 \mathrm{~F} / 2 \mathrm{M}(\sim 45) \\
4 \mathrm{~F} / 3 \mathrm{M}(\sim 40)\end{array}$ \\
\hline $\begin{array}{l}\text { 3. Central } \\
\text { Ostrobothnia } \\
\text { (Perho) }\end{array}$ & $\begin{array}{l}2(2017) \\
1(2018)\end{array}$ & $\begin{array}{l}\text { MG (1), BF (4), CA (1) } \\
\text { MG (1), BF (5), CA (1) } \\
\text { MG (1), BF (16), EC (2), CA (1) }\end{array}$ & $\begin{array}{l}1 \mathrm{~F} / 5 \mathrm{M}(\sim 40) \\
1 \mathrm{~F} / 6 \mathrm{M}(\sim 40) \\
1 \mathrm{~F} / 19 \mathrm{M}(\sim 40)\end{array}$ \\
\hline $\begin{array}{l}\text { 4. Lapland } \\
\text { (Tervola) }\end{array}$ & $1(2017)$ & MG (3), BF (2), CA (2) & $6 \mathrm{M} / 1 \mathrm{~F}(\sim 50)$ \\
\hline $\begin{array}{l}\text { 5. Lapland } \\
\text { (Sodankylä) }\end{array}$ & $1(2017)$ & MG (2), BF (2), EC (1), CA (1) & $1 \mathrm{~F} / 5 \mathrm{M}(\sim 45)$ \\
\hline
\end{tabular}




\section{Ideologies in Energy Transition: Community Discourses on Renewables}

Petra Berg, Rumy Narayan and Arto Rajala

Table 2. Ideological Discourses

\begin{tabular}{|c|c|c|c|}
\hline Ideological Discourses & Clan & Solarpunk & Native \\
\hline Orientation or Ideals & $\begin{array}{l}\text { Utilitarian, altruistic, } \\
\text { traditional, collective to } \\
\text { individual. }\end{array}$ & $\begin{array}{l}\text { Techno-utopian, } \\
\text { individualistic. }\end{array}$ & $\begin{array}{l}\text { Nature-centered, altruistic, } \\
\text { individual to collective. }\end{array}$ \\
\hline Manner of talk & $\begin{array}{l}\text { Realistic, informal } \\
\text { language, talk like locals, } \\
\text { dialect. }\end{array}$ & $\begin{array}{l}\text { Passionate and innovative, } \\
\text { use of formal, expert } \\
\text { language. }\end{array}$ & $\begin{array}{l}\text { Emotional language, mix of } \\
\text { expert and informal } \\
\text { (dialect) language. }\end{array}$ \\
\hline $\begin{array}{l}\text { Sense-making - rationale } \\
\text { "why renewable energy } \\
\text { solutions" }\end{array}$ & $\begin{array}{l}\text { Local, bio-based solutions } \\
\text { bring local welfare. We } \\
\text { need to maintain our } \\
\text { traditional system of } \\
\text { production, but on a } \\
\text { reasonable scale. We need } \\
\text { to slow down global } \\
\text { growth and focus on small } \\
\text { scale, national, and local } \\
\text { production and } \\
\text { consumption. }\end{array}$ & $\begin{array}{l}\text { New technological } \\
\text { solutions and innovations } \\
\text { bring local welfare and } \\
\text { help save the planet as } \\
\text { well. Growth and } \\
\text { development must } \\
\text { continue "but we can do it } \\
\text { better, smarter and more } \\
\text { sustainably". }\end{array}$ & $\begin{array}{l}\text { Nature is sacred; we need } \\
\text { to change our perspective } \\
\text { towards the "native view". } \\
\text { We are part of the natural } \\
\text { system and need to adapt } \\
\text { and change the way we } \\
\text { produce and consume } \\
\text { products and services. } \\
\text { Solutions to tackle climate } \\
\text { change and biodiversity } \\
\text { loss should drive the } \\
\text { transition. }\end{array}$ \\
\hline Core beliefs & $\begin{array}{l}\text { Relying on experts to } \\
\text { measure correct things; } \\
\text { trusting and supporting } \\
\text { current knowledge. }\end{array}$ & $\begin{array}{l}\text { Facts \& figures everything } \\
\text { should be measured, we } \\
\text { can manage and control } \\
\text { nature. }\end{array}$ & $\begin{array}{l}\text { Questioning given truths. } \\
\text { Not everything can be } \\
\text { measured - quality of life is } \\
\text { not measurable. }\end{array}$ \\
\hline $\begin{array}{l}\text { Attributes given to the } \\
\text { discourse }\end{array}$ & $\begin{array}{l}\text { Reliable and trustworthy, } \\
\text { getting along with others, } \\
\text { "do not upset the clan". } \\
\text { Flirtatious. }\end{array}$ & $\begin{array}{l}\text { Expert and "high flier", } \\
\text { good contact, outside the } \\
\text { clan. Expanding horizons } \\
\text { and developing new ideas. } \\
\text { "We spirit" - believe in } \\
\text { future opportunities. }\end{array}$ & $\begin{array}{l}\text { Preserving nature, utopian, } \\
\text { un-realistic, too emotional, } \\
\text { does not understand } \\
\text { reality. Luddite, even } \\
\text { verging on radical. Driving } \\
\text { for change. }\end{array}$ \\
\hline $\begin{array}{l}\text { Contradictions expressed } \\
\text { by discourses }\end{array}$ & $\begin{array}{l}\text { Too radical or "foreign" } \\
\text { ideas threaten local ways. } \\
\text { Outside rules and } \\
\text { regulations can be } \\
\text { problematic but must be } \\
\text { followed. } \\
\text { City Greens, vegan } \\
\text { "treehuggers", and } \\
\text { Luddites, create } \\
\text { unnecessary problems! }\end{array}$ & $\begin{array}{l}\text { Slow pace, rigid structures, } \\
\text { incremental, conformism } \\
\text { are in the way of new } \\
\text { opportunities! } \\
\text { Wrong technology, stupid } \\
\text { choices (not enough } \\
\text { knowledge), lack of facts. } \\
\text { Too many rules and } \\
\text { regulations! }\end{array}$ & $\begin{array}{l}\text { People do not listen; nature } \\
\text { is not given a voice. Radical } \\
\text { system-wide changes are } \\
\text { needed - downshifting, etc. } \\
\text { "Redneck" mentality and } \\
\text { not being taken seriously! }\end{array}$ \\
\hline What drives actors & $\begin{array}{l}\text { Safety \& reliability } \\
\text { Incremental innovations }\end{array}$ & $\begin{array}{l}\text { Progress \& technology } \\
\text { New Innovations }\end{array}$ & $\begin{array}{l}\text { Biodiversity \& climate } \\
\text { Radical Innovations }\end{array}$ \\
\hline Transition role & $\begin{array}{l}\text { The ones maintaining a } \\
\text { system - the "doers". } \\
\text { Difficult-to-change } \\
\text { mindset, together with } \\
\text { conflict-avoidance. } \\
\text { Needs time to digest and } \\
\text { prove of functionality. } \\
\text { Securing local balance - } \\
\text { security - sustaining. }\end{array}$ & $\begin{array}{l}\text { The leader or catalyst. } \\
\text { Lots of knowledge and } \\
\text { information that might "get } \\
\text { lost" - How to capture it } \\
\text { into transition processes? } \\
\text { Conflict might be } \\
\text { inevitable. } \\
\text { Mostly still embedded in } \\
\text { the institutions and regime. } \\
\text { Hard to make decisions } \\
\text { that are truly radical even } \\
\text { if this group has the } \\
\text { capacity. }\end{array}$ & $\begin{array}{l}\text { Nature's voice - challenger } \\
\text { of dominant system. } \\
\text { The "hidden" discourse. } \\
\text { There could be more "fence } \\
\text { sitters" who cannot take } \\
\text { this position openly. } \\
\text { Constant conflict. } \\
\text { Might be capable of } \\
\text { thinking outside the box. } \\
\text { The energy of cultural } \\
\text { "misfits" open for radical } \\
\text { innovation. Often lacking } \\
\text { the know-how and support } \\
\text { from others. }\end{array}$ \\
\hline
\end{tabular}




\section{Ideologies in Energy Transition: Community Discourses on Renewables}

\section{Petra Berg, Rumy Narayan and Arto Rajala}

our livelihood". After this initial phase, we merged the emerging textual structures and scrutinized them to find convergence, especially looking for various logics and constructs about renewable energy. As a result, we identified three different ideological discourses and labelled them as: Clan, Solarpunk and Native.

\section{Findings}

Ideologies, Meta Discourses, and Sensemaking

We excavated discourses from the texts by merging themes and structures into coherent storylines about the renewable energy reality constructed by different people. The three different ideological discourses and their characteristics are presented in Table 2.

In the following sections, we coded the citations according to the classification in Table 1. Participant backgrounds: MG (representatives of municipality), BF (local businesses/farmers), EC (energy companies), CA (consulting agencies); Regions ( 1 = Vaasa/Vähäkyrö, 2 $=$ Kristinestad, 3 = Perho, $4=$ Tervola, $5=$ Sodankylä).

\section{Clan}

"Why are you making this so complicated?" The Clan ideological discourse is constructed based on respect of long lasting, local traditions, as well as existing rules and norms. To maintain municipal well-being, local economic growth is necessary. Since the natural resources belong to the people, they can be used thereby continuing the traditional ways of mining, forestry, fishing, farming and agriculture.

"There is a need to understand local actors, peoples' needs and wants ... the aim is to see the big picture of what the region could gain and not go into technology first" (MG 5).

In this discourse, traditional values meet the belief in technological solutions. While there is a contradiction between keeping things as they have always been and achieving changes at the same time, there is also a strong belief in technology that has proven its utility. The Clan discourse uses words such as reason, proof and realism as ways to achieve goals. Being cautious and avoiding unnecessary "foolish" risks are Clan virtues. This ideology stands for an "innate predisposition" to look for incremental innovations that do not disturb the existing system.

\begin{abstract}
"Yes, and if you take that 'X-pilot' as a good example, they are using the 'company Alpha' as supplier. And the owner told us that indeed, today their biogas production brings more income than the traditional farming" (BF 3).
\end{abstract}

In fact, the current Finnish bio-economy agenda provides a supporting rationale for this ideology, as the ownership of land and what is called "everyman's rights" person's-right to use its resources lies at the heart of this discourse. A concern persists about sustainability issues, for example, such as climate change mitigation and making the environment cleaner. These arguments are frequently mentioned and considered as the "positive side effects" of economically rational investments.

"Cutting emissions is one of these side effects we want to achieve with this new business ... as well as restoring the natural environment" (MG 3).

Accordingly, the Clan ideology resonates with the rational ideology mentioned by Mees-Buss and Welch (2019), where emphasis is given to logical thinking, seeing systems (nature) rather as machines, with processes driven by objective decisions. In the Clan discourse, emotions get downplayed while duties highlighted. At the same time, human, social aspects such as consensus and mutual agreement are mentioned frequently.

"So the main point was to get more projects, new businesses, investments and more jobs for the local people" (CA 5).

Similarly, incentives to participate in local energy transition often come from the promise of economic gain.

\section{"There's many of us here today because meat, milk and cereal production does not bring enough incomes anymore" (BF 3).}

This ideology proposes love of land and its cultivational traditions, which exert a utilitarian approach, centered on the human right to use the land. Accordingly, opportunities in the field of renewable energy are often talked about in connection to bio-economy strategies. The Clan ideological discourse expresses trust towards national institutions and their guidelines regarding the use of natural resources. 


\section{Ideologies in Energy Transition: Community Discourses on Renewables}

\section{Petra Berg, Rumy Narayan and Arto Rajala}

\begin{abstract}
"Regarding the bio-economy; we have enough raw materials, we know that the forests are growing faster now as the climate is warming up... and we are very good at working with wood products, and different metals... obviously, the bio-economy requires these skills" (MG 4).
\end{abstract}

The Clan ideology appears as "the maintaining discourse of the regime", an incumbent mindset that proposes trust in existing institutional structures and their experts. The national experts are trusted (sometimes reluctantly) to provide the right information about how to use one's resources and make a living. This could also be called the "I told you so" discourse, as it draws from the security of adhering to existing moral codes and norms.

\section{Solarpunk}

This ideology consists of a strong belief that modern technology will "save the world" (Humphreys, 2014), making it possible to meet bio-economy goals and at the same time "save the planet". In this view, modern and smart technology can provide biological resources that will bring sustainable and positive change. The Solarpunk discourse uses words like smart, innovation, new possibilities, and competition when talking about future opportunities for Finnish municipalities.

"Here, in my opinion, the big thing is that the entire energy sector seems to be in transition. And these new operational models are coming in any case, and the one who grabs this opportunity and starts doing new things, will have a competitive advantage that might turn out as a pretty significant one" (CA 5).

In this discourse, opportunities are based upon natural resources: forests, minerals, rivers, and soil are all resources that should be used in a modern and sustainable manner. In the Solarpunk ideology, responsible utilization of natural resources will be the next step of energy transition as new technological solutions enable extracting multiple values without causing unnecessary harm. For instance, forest-based biomass can be processed into high value products, and minerals can be mined without environmental pollution. All these are thanks to advanced technological solutions and rigorous control of natural resources by experts.
For this discourse it is important to avoid being accused of irrational "green thinking" or of so-called "Luddite traits" (Humphreys, 2014), even if peoples' underlying values might be in that direction. The best way to avoid accusations of too much "green ideology" is to highlight the economic benefits of sustainable approaches.

"The state of the fields should be considered, and you might want to leave the straw on the land as it leads to better soil.... The same goes for stubs as they should be left in the forests.... Many opportunities to make money here!" (BF 1).

The Solarpunk ideology wants to combine the best of two worlds, nature and technology, in a way that promises social well-being for all people. It also acknowledges various aspirations that might exist in local contexts, indicating possible altruistic motives about why action is required.

"Not everyone will just calculate euros, they want to act because of personal principles and environmental reasons" (BF 3).

The Solarpunk ideology builds mainly upon strong beliefs in scientific knowledge, and the contribution of innovations for building better and resilient societies. It definitely holds a place for new, even radical innovations, within a discourse that can propose the remaking of existing energy systems.

"Well, as I looked at these (statistics) for the first time today, I got the feeling that there is a lack of market actors (in the bio-energy sector), and we have business and other actors who might want to join this ... but the other part is somewhere else, good networks, collaboration ... and we are good at collaboration ... so there might be a need for new models of financing that we would come up with, our own models" (CA 3).

Technological and human development go hand in hand. The choices of energy sources and technological systems, as well as their business logics, are considered as being in transition, while new solutions are emerging. Central to the Solarpunk ideology is the belief that technological solutions, such as AI (Artificial Intelligence) and smart systems, are entering our lives anyway. The radical and the passionate "no-risk-no-fun approach" makes this ideological discourse closer to a 


\title{
Ideologies in Energy Transition: Community Discourses on Renewables
}

\author{
Petra Berg, Rumy Narayan and Arto Rajala
}

normative ideology (Mees-Buss \& Welch, 2019) by attributing greater importance to contribute something meaningful and make a difference for the world. This discourse also mirrors the findings by von Koskull and colleagues (2018) concerning arguments drawn from logical evidence such as data and rational argumentation.

\section{Native}

The Native ideology connects with values that are often referred to as altruistic or "native", meaning where human beings are seen as a part of a bigger, natural order and not its owner. Nature has its limits that should be respected and maintained (Humphreys, 2014). This ideology proposes collective and inclusive actions, where value comes from social and ecological well-being along with economic gains that serve as means to maintain a balanced system.

This discourse includes softer vocabulary such as nurture, care, consideration, well-being, and it might also be used as a disguise to safely express ideas and values that are not considered legitimate within the current system. For instance, talking about "the other" who has some weird ideas but might make a good point about certain things. Interestingly, in the energy village context the Native ideology is often attributed to "Southerners", which refers to people in the capital area living some $500 \mathrm{~km}$ south of Ostrobothnia or 1,000 $\mathrm{km}$ south of Lapland.

"It seems that biogas is a future fuel, in the south they already use gas fueled cars in the cities" (BF 3).

The Native discourse calls for collaboration and diversity in decision making, as well as avoiding unnecessary hierarchies. As it contests the dominant logic of (market) competition, it easily evokes the fears of green-red coalitions and "hippie" ideologies that have traditionally been associated with organic farming, and Luddites of all kind (Humphreys, 2014). The combination of environmental protection and a green orientation can be perceived as a challenge, as they produce an ideological stance that questions the way land and natural resources should be used. This way it opposes the legitimacy of the current dominant and legitimized system (Press et al., 2014).

"And then (seen as a challenge to local energy development), as you can see with RED II (EU

\begin{abstract}
Renewable Energy Directive) and the way it directs policy, European environmental protection and green values have a strong impact" (MG 4).
\end{abstract}

Expressions of the Native ideology are strongest when it comes to discussions about climate change and its impact on livelihood in municipalities.

\section{"I was wondering about the image of renewable energy... Is it taken seriously or is it thought about as nonsense? ... I think it is evolving all the time, and now, people talk about changes in the environment a lot, like we've had quite a few grey Christmases" (BF 1).}

Technology is also used in a curious way as an entry point to express green values, as it provides a "neutral space" in the discussions.

"My interest is generally in renewable energy, and I have considered buying that solar power system (PV) and otherwise as well ... I want more information about other options, biogas would be interesting for the car and so on" (BF 3).

The Native discourse is constructed as a "weak discourse" in the municipal energy transition context; it is as a third force that it is referred to, mostly as an opposing force, by the other discourses. This ideology draws from both rational and normative stances (MeesBuss \& Welch, 2019), while holding ecological values at its core. This is in line with believing nature is sacred ideology where ecosystems have a value of their own and nature should be protected from extractivism and technology (Humphreys, 2014).

To sum up, our findings show three basic ideological discourses in energy transition at the municipal level: Clan, Solarpunk, and Native. Together these discourses highlight the complexity of socio-cultural structures speeding up, or slowing down, acceptance and action towards using local renewables in energy production and consumption.

Discourses circulate as meaning structures in energy arenas, which are carried by all their actors who then put more emphasis on certain structures. Accordingly, no discourse is exclusive, while at the same time a person can carry and represent multiple discourses. Collective beliefs and ideologies affect a person's choice of 


\title{
Ideologies in Energy Transition: Community Discourses on Renewables
}

\author{
Petra Berg, Rumy Narayan and Arto Rajala
}

\section{discourses.}

In the following section we will discuss more in depth about the theoretical and managerial implications of these discourses.

\section{Discussion}

\section{Contribution to theory}

This paper takes a social-constructionist perspective on energy transitions involving municipalities. Our findings show that energy transitions at the municipal level in Finland are strongly affected by small groups of actors in key roles. These findings are in line with earlier research carried out by Ruggiero and colleagues (2015). Wanting radical innovations that enable regions to take leaps towards more sustainable ecosystems creates pressure on transition managers in how far they are prepared to go in putting pressure and challenging the local "doxa" (Press et al., 2014). Entering a municipal context where institutional belief systems have long been fixed, such as in rural areas with actors mostly adhering to the Clan ideology, initially paves the way for certain, mostly incremental innovations, while more radical ones gain less support and interest as they are not founded in the local worldview.

With the expectation that local transition happens in a democratic way (Avelino \& Wittmayer, 2016), local people are asked to join and vote for solutions. However, our results show that the underlying social hierarchies also affect who will be active in such collective occasions. We noticed that most workshops and meetings followed the same pattern, where almost all participants were $40+$ year-old men. Only in one case (Kristinestad), were half of the participants in the events women (see Table 1.). This lack of diversity might have some interesting implications regarding the dominant ideologies that reflect what kinds of discourses are socially acceptable in local contexts. Especially, the least common Native ideological discourse is driven by values that are traditionally considered as "softer or feminine" (Hultman \& Anshelm, 2017). Also, Westerlund (2020) found that women in Finland are more supportive of sustainable energy than men. Thus, women may also favor more radical energy-related innovations to be implemented at the local level as well.

\begin{abstract}
Implications to practice
Most municipal-level renewable energy related activities seem to be connected to bio-based production, and thus the bio-economy agenda. This means the involvement of authorities such as the Finnish Food Authority and the Centres for Economic Development, Transport and the Environment are responsible for regional implementation. The closeness to or distance from institutional requirements, normative and legislative frameworks becomes tangible in the different discourses. This is especially evident in the Solarpunk discourse where better technological solutions and innovations are believed to bring welfare to local communities and municipalities. It is believed that "the planet can be saved" by using enhanced better technical solutions, such as cheaper PV systems, small and effective bio gas reactors, and geothermal or air source heat pumps.
\end{abstract}

This kind of top-down driven development can be highlighted by a case such as wind power, which is not considered as an opportunity for local business actors due to its complexity and required capital intensity. Simultaneously, the dominant agenda of existing (and new) nuclear power plants and their related agenda seems to be pushing urgency related to climate change issues into the background, ironically while indicating to local energy producers that these issues are too big to be managed by local energy producers. This reveals a topdown decision-making approach, yet part of the climate objective aims clearly to devolve the decision-making processes to regional levels.

The forest sector (and its by-products) appears to be high on the agenda as far as solutions for Finnish renewable energy transition is concerned. As the purpose of the ESSR project was to support more locally produced renewable energy, and as all the participating regions and municipalities have rich forest resources and agricultural production, bio-resources are easily given the upper hand. This focus on the forest sector might create certain kinds of technological (path) lockins from the very beginning, especially as the leading ideological discourses in these municipalities seem to lean towards the Clan, and its techno-utilitarian way of doing things. From the perspective of sustainable transitions, the Finnish "forest is our green gold" ideology is tightly interwoven into the dominant ideological landscape of rural Finland. Thus, it becomes clear that local actors want to maintain their rights to 


\title{
Ideologies in Energy Transition: Community Discourses on Renewables
}

\author{
Petra Berg, Rumy Narayan and Arto Rajala
}

use their biggest asset. On the other hand, Finland as well as Sweden, have received global and EU-level criticism for unsustainable national guidelines regarding the use of forests, suggesting the post-2020 EU vision of forest-based climate mitigation may be hampered (Ceccherini et al., 2020).

\section{Limitations and future studies}

This qualitative study was based on a rather small number of cases. However, these cases are representative examples of the emerging decentralized and renewable energy production in Finland. It seems, that taking into account the traditional and utilitarian tones of the dominant discourses found in municipal energy contexts in Finland, more research is needed on regulative guidelines and their support to put forward more sustainable energy transition. Considering the power of ideological discourses at the local level, the intangible but real discursive forces that have the power either to legitimize or downplay local actors' ideas and aspirations, the managers of transition processes need to become aware of them. We have learned during our research that in one local context, there might exist different ideologies, logics, hierarchies as well as "forbidden" positions. Questions for transition managers include: First, by what means do we need to be clear about how big the changes are that we really need to achieve, and, second, how can we support the change agents who have the hands-on task of engaging local actors?

\section{Conclusion}

While collective norms and habits may manifest as ideological constructs, uncovering and understanding what underlies ideologies in municipal collectives is crucial for identifying what kinds of forms and structures these new energy systems might take. The ideological positioning on the municipal level obviously affects the acceptance of new energy solutions. Our findings indicate that ideological structures have the power to create material outcomes. By understanding the ideological map of an energy arena, a transition manager has the opportunity to choose tools and avoid biases that might hamper sustainability outcomes. We suggest that both municipal authorities and regional agencies should strive for a broader sense-making view of the three identified ideological discourses identified in this paper: Clan, Solarpunk, Native. In practice, this means that several actors with different worldviews need to be engaged collaboratively for initializing, designing, and implementing actions needed for local energy transition.

\section{Acknowledgments}

A previous version of this paper was published in Berg, P. 2021. Power of Myths in Energy Transition: Unveiling Timeless Mythologies in Finnish Energy Agora. University of Vaasa: Acta Wasaensia 458 (Dissertation). ISBN 978952-476-948-8 (print), 978-952-476-949-5 (online) http://urn.fi/URN:ISBN:978-952-476-949-5

We want to thank the following institutions and projects for financial support: University of Vaasa, School of Marketing and Communication, and VEBIC (Vaasa Energy Business Innovation Center) research platform; South Ostrobothnia Regional Fund of the Finnish Cultural Foundation; Business Finland, FLEXIMAR (Novel marketplace for energy flexibility) and SolarX (Maximizing PV integration capacity in energy and power systems) projects; European Regional Development Fund, ESSR (Energy Self-Sufficient Regions) project; and the Foundation for Economic Education, PETs (Pathways to Energy Transitions) project. 


\title{
Ideologies in Energy Transition: Community Discourses on Renewables
}

\author{
Petra Berg, Rumy Narayan and Arto Rajala
}

\section{References}

Avelino, F., \& Wittmayer J.M. 2016. Shifting Power Relations in Sustainability Transitions: A Multi-actor Perspective. Journal of Environmental Policy \& Planning, 28(5): 628-649.

DOI: https://doi.org/10.1080/1523908X.2015.1112259

Berger, P.L., \& Luckmann, T. 1967. The Social Construction of Reality - A Treatise in the Sociology of Knowledge. Anchor Books, Doubleday and Company, New York.

Burton, J., \& Hubacek, K. 2007. Is Small Beautiful? A multicriteria assessment of small-scale energy technology applications in local governments. Energy Policy, 35 (12): 6402-6412.

DOI: https://doi.org/10.1016/j.enpol.2007.08.002

Ceccherini, G., Duveiller G., Grassi G. et al., 2020. Abrupt Increase in Harvested Forest Area over Europe after 2015. Nature 583: 72-77.

DOI: https://doi.org/10.1038/s41586-020-2438-y

Coenen, L., Benneworth P., \& Truffer B. 2012. Toward a Spatial Perspective on Sustainability Transitions. Research Policy, 41(6): 968-979.

DOI: https://doi.org/10.1016/j.respol.2012.02.014

Dóci, G., Vasileiadou, E. \& Petersen, A.C., 2015. Exploring the Transition Potential of Renewable Energy Communities. Futures, 66: 85-95.

DOI: https://doi.org/10.1016/j.futures.2015.01.002

Eagleton, T. 2007. Ideology: An Introduction. New York: Verso.

Ellis, C., 2007. Telling Secrets, Revealing Lives: Relational ethics in research with intimate others. Qualitative Inquiry, 13(1): 3-29.

DOI: https://doi.org/10.1177\%2F1077800406294947

Fairclough, N. 2005. Peripheral Vision: Discourse analysis in organization studies: The case for critical realism. Organization Studies, 26(6): 915-939.

DOI: https://doi.org/10.1177\%2F0170840605054610

Farla, J., Markard, J., Raven, R., \& Coenen, L. 2012. Sustainability Transitions in the Making: A closer look at actors, strategies and resources. Technological forecasting and social change, 79(6): 991-998.

DOI: https://doi.org/10.1016/j.techfore.2012.02.001

Freeden, M. 2003. Ideology: A Very Short Introduction. Oxford, UK: Oxford University Press

Geels, F.W. 2020. Micro-foundations of the Multi-level Perspective on Socio-technical Transitions: Developing a multi-dimensional model of agency through crossovers between social constructivism, evolutionary economics and neo-institutional theory. Technological Forecasting \& Social Change, 152.

DOI: https://doi.org/10.1016/j.techfore.2019.119894
Giesler, M. \& Veresiu, E. 2014. Creating the Responsible Consumer: Moralistic Governance regimes and Consumer Subjectivity. Journal of Consumer Research, 41: 840-857.

DOI: https://doi.org/10.1086/677842

Haase, M. \& Raufflet, E. 2017. Ideologies in Markets, Organizations, and Business Ethics: Drafting a Map: Introduction to the Special Issue. Journal of Business Ethics, 142: 629-639.

DOI: https://doi.org/10.1007/s10551-016-3302-8

Hultman, M. \& Anshelm, J. 2017. Masculinities of Climate Change. Exploring examples of industrial-, ecomodern-, and ecological masculinities in the age of Anthropocene. In: Climate Change and Gender in Rich Countries: work, public policy and action. Ed. Marjorie Griffin Cohen, Abingdon/New York: Routledge, 1: 19-34.

Humphreys, A. 2014. How is Sustainability Structured? The Discursive Life of Environmentalism. Journal of Macromarketing, 34: 265-281.

DOI: https://doi.org/10.1177\%2F0276146714521238

Jorgensen, M., \& Phillips, L. 2002. Discourse Analysis as Theory and Method. London: Sage.

Kainiemi, L., Karhunmaa, K., \& Eloneva, S. 2020. Renovation Realities: Actors, institutional work and the struggle to transform Finnish energy policy. Energy Research \& Social Science, 70.

DOI: https://doi.org/10.1016/j.erss.2020.101778.

Kilbourne, W.E., \& Mittelstaedt, J. 2012. From Profligacy to Sustainability. In: Transformative Consumer Research - For Personal and Collective Well-being. Ed. Mick D.G, Pettigrew S., Pechmann C. \& Ozanne J.L. Routledge, Taylor \& Francis Group, LLC: USA: 283300.

Kilbourne, W., McDonagh, P., \& Prothero, A. 1997. Sustainable Consumption and the Quality of Life: A Macromarketing Challenge to the Dominant Social Paradigm. Journal of Macromarketing, 17(1): 4-24. DOI: https://doi.org/10.1177\%2F027614679701700103

Kostevšek, A., Petek, J., Klemeš, J.J., \& Varbanow, P. 2016. Municipal Energy Policy Constitution and Integration Process to Establish Sustainable Energy Systems - a case of the Slovenian municipality. Journal of Cleaner Production, 120: 31-42.

DOI: https://doi.org/10.1016/j.jclepro.2016.01.046

Mannberg, A., Jansson, J., Pettersson, T., Brännlund, R., \& Lindgren, U. 2014. Do tax incentives affect households' adoption of "green" cars? A panel study of the Stockholm congestion tax. Energy Policy, 74(0): 286-299.

DOI: https://doi.org/10.1016/j.enpol.2014.08.029

Marion, G. 2006. Marketing Ideology and Criticism: Legitimacy and Legitimization. Marketing Theory, 6 (2): 245-262.

DOI: https://doi.org/10.1177\%2F1470593106063985 


\section{Ideologies in Energy Transition: Community Discourses on Renewables}

\section{Petra Berg, Rumy Narayan and Arto Rajala}

Mees-Buss, J., \& Welch, C. 2019. Managerial Ideologies Dividing the Corporate Elite: A process study of the rise and fall of a counter-ideology. Organization Studies, 40(4): 563-592.

DOI: https://doi.org/10.1177\%2F0170840617747920

Olkkonen, L., Korjonen-Kuusipuro, K., \& Grönberg, I. 2017. Redefining a Stakeholder Relation: Finnish energy "prosumers" as co-producers. Environmental Innovation and Societal Transitions, 24: 57-66.

DOI: https://doi.org/10.1016/j.eist.2016.10.004

Peura, P., Haapanen, A., Reini, K., \& Törmä, H. 2018. Regional Impacts of Sustainable Energy in Western Finland. Journal of Cleaner Production, 187: 85-97. DOI: https://doi.org/10.1016/j.jclepro.2018.03.194

Press, M., Arnould, E., Murray, J.B., \& Strand, K. 2014. Ideological Challenges to Changing Strategic Orientation in Commodity Agriculture. Journal of Marketing, 78: 103-119.

DOI: https://doi.org/10.1509\%2Fjm.13.0280

Ringberg, T., Reihlen, M., \& Rydén, P. 2019. The Technology-mindset Interactions: Leading to incremental, radical or revolutionary innovations. Industrial Marketing Management, 79:102- 113. DOI:

https://doi.org/10.1016/j.indmarman.2018.06.009

Ruggiero, S., Varho, V., \& Rikkonen, P. 2015. Transition to Distributed Energy Generation in Finland: Prospects and barriers. Energy Policy, 86: 433-443. DOI: https://doi.org/10.1016/j.enpol.2015.07.024

Salignac, F. 2012. Discourse Analysis. Handbook of Research Methods on Social Entrepreneurship, edited by Richard Seymour, Edward Elgar Publishing, Incorporated.

Sarrica, M., Brondi, S., Cottone, P., \& Mazzara, B.M. 2016. One, No One, One Hundred Thousand Energy Transitions in Europe: The quest for a cultural approach. Energy Research \& Social Science, 13: 1-14. DOI: https://doi.org/10.1016/j.erss.2015.12.019

Schenk, N.J., Moll, H.C., \& Uiterkamp, A.J.S. 2007. Meso-level Analysis, the Missing Link in Energy Strategies. Energy Policy, 35(3): 1505-1516.

DOI: https://doi.org/10.1016/j.enpol.2006.04.013

Sengers, F., Wieczorek, A.J. \& Raven, R. 2019. Experimenting for Sustainability Transitions: A systematic literature review. Technological Forecasting and Social Change, 145:153-164.

DOI: https://doi.org/10.1016/j.techfore.2016.08.031

Späth, P. \& Rohracher, H. 2010, Energy Regions: The transformative power of regional discourses on socio-technical. Research Policy, 39(4): 449-458.

DOI: https://doi.org/10.1016/j.respol.2010.01.017

Stirling, A. 2014. Transforming Power: Social science and the politics of energy choices. Energy Research \& Social Science, 1: 83-95.

DOI: https://doi.org/10.1016/j.erss.2014.02.001
Van Der Schoor, T., \& Scholtens B. 2015. Power to the People: Local community initiatives and the transition to sustainable energy. Renewable and Sustainable Energy Reviews, 43: 666-675.

DOI: https://doi.org/10.1016/j.rser.2014.10.089

Van Dijk, T.A. 2006. Ideology and Discourse Analysis. Journal of Political Ideologies, 11(2): 115-140.

DOI: https://doi.org/10.1080/13569310600687908

Westerlund, M. 2020. Social Acceptance of Wind Energy in Urban Landscapes. Technology Innovation Management Review, 10(9): 50-62.

DOI: http://doi.org/10.22215/timreview/ 1389

Von Koskull, C., Berg, P. \& Gummerus, J., 2018. Wrath in Consumer Oppositional Activism. In: Seven Deadly Sins in Consumption. Syrjälä, Henna \& LeipämaaLeskinen, Hanna (Eds.). Edward Elgar Publishing.

Weick, K.E., 1995. Sensmaking in Organizations. Thousand Oaks, CA: SAGE Publications.

Wittmayer, J.M., Avelino, F., van Steenbergen, F., \& Loorbach, D. 2017. Actor Roles in Transition: Insights from sociological perspectives. Environmental Innovation and Societal Transitions, 24: 45-56. DOI: https://doi.org/10.1016/j.eist.2016.10.003.

Ym.fi 2019. Towards Climate-Smart Day-to-Day Living Medium-term Climate Change Plan to 2030. Ministry of the Environment. [Online] [Cited on 6.6.2019] Available from:

https://www.ym.fi/en-

US/The_environment/Climate_and_air/Mitigation_of climate_change/National_climate_policy/Climate_C hange_Plan_2030. 


\section{Ideologies in Energy Transition: Community Discourses on Renewables}

\section{Petra Berg, Rumy Narayan and Arto Rajala}

\begin{abstract}
About the Authors
Petra Berg is a Post Doc Researcher at the School of Marketing and Communication as well as the VEBIC platform, University of Vaasa, Finland. She holds a D.Sc. (Econ.) in Marketing. Dr. Berg has been participating as a project researcher, as well as coordinating proposal writing for national and EU (H2020) projects in sustainability, food and energy related areas. For the moment, she is teaching sustainability transitions and responsible business, while participating in the Biogas Utilization Opportunities in Ostrobothnia Region project. Her research interests are in the fields of Macromarketing, energy behavior and transition management, with sustainability transitions and social-cyber-physical energy systems as her main focus.

Rumy Narayan studies transitions to sustainable energy systems. Her research interests fall within a framework of innovation possibilities that could potentially address pressing global challenges of our time, while stimulating societal and economic prosperity. This entails activating innovations across sectors, actors, and disciplines, while enabling experimentation, a complex process that needs appropriate tools for coordinating and managing diverse networks. Within this context, blockchain has gained in relevance for her research as an institutional and social technology for managing and coordinating disparate networks of actors.
\end{abstract}

Arto Rajala (M), D.Sc. (Econ.), is a Professor of Marketing at the School of Marketing \& Communication in University of Vaasa. He is the leader of the school's marketing research group. He also holds the Title of Docent (Entrepreneurial Marketing) at the Lappeenranta University of Technology, Finland. Rajala's research interest and special expertise are related to business-tobusiness marketing, business networks, and renewable energy marketing. He has published several articles on business networks and their management, SME growth and innovativeness, and marketing capabilities. Rajala has more than 20 years' experience of teaching and program coordination at the University of Vaasa and Aalto University (Finland). Currently, Rajala is leading and involved in several international and national interdisciplinary projects related to energy, for example, Erasmus+ (Furn360 and EntRNEW), H2020 (IRIS Smart City, OpenInnoTrain, and RIPEET), and Business Finland (FLEXIMAR and SolarX). In these projects, renewable energy, citizen engagement as well as energy communities and prosumers are core topics.

Citation: Berg, P., Narayan, R., Rajala, A. 2021. Ideologies in Energy

Trasition: Community Discourses on Renewables. Technology Innovation

Management Review, 11 (7/8): 79-91.

*http://doi.org/10.22215/timreview/1458

Keywords: Renewable Energy, Sustainability Transitions, Ideological Discourses, Sense making, Municipal Energy Transition

(cc) BY 